\title{
Characteristics of the Gustatory Organs on the Tongue of the Chinese Fire-bellied Newt (Cynops orientalis): Light and Scanning Electron Microscopy Study
}

\author{
Características de los Órganos Gustativos en la Lengua del Tritón Vientre de Fuego \\ Chino (Cynops orientalis): Estudio por Microscopía de Luz y Electrónica de Barrido
}

Zhaohui Xie*; Jingting Li** \& Pu Cheng*

XIE, Z.; LI, J. \& CHENG, P. Characteristic of the gustatory organs on the tongue of the chinese fire-bellied newt (Cynops orientalis): light and scanning electron microscopy study. Int. J. Morphol., 32(3):930-934, 2014.

SUMMARY The dorsal surface of the tongue gustatory organs of Chinese fire-bellied newt (Cynops orientalis) was observed by employing the light and scanning electron microscopy (SEM) techniques. The results revealed that the rostral and median part of the tongue presents a round apex and covered by taste disks (TDs). They are usually roundish or ellipsoidal in shape and are $20-35 \mathrm{~mm}$ in diameter. The many openings of the lingual glands are $4-8 \mathrm{~mm}$ in diameter exist in the lateral border or median part of lingual body. The gustatory organs on the tongue did not differed form those presented in other species in Caudates. These may indicate the functions of gustatory organs on the tongue related to their life habit.

KEY WORDS: Tongue; Lingual epithelium; Histology; Taste disks; Caudates.

\section{INTRODUCTION}

Many studies have demonstrated that the gustatory organs on the tongue of vertebrates in the form of taste buds (TBs) (Iwasaki, 2002; Mistretta \& Liu, 2006; Abbate et al., 2010). However, previous morphological descriptions of gustatory organs in developing Anurans showed that there are two successive generations of taste organs: premetamorphic TBs in larval forms and taste disks (TDs) in postmetamorphic animals (Graziadei \& DeHan, 1971; Zylberberg, 1977; Iwasaki et al. 1989a, 1989b; Witt, 1993; Osculati \& Sbarbati, 1995; Zuwala, 2002; Iwasaki \& Wanichanon, 2005). In adult specimens of Caudata such as Salamandra salamandra (Zuwala \& Jakubowski, 2001), Hynobius dunni (Zuwalla et al. 2002) and Triturus alpestris (Zuwala \& Jakubowski, 2007) have been investigated that taste disks structure as gustatory organs, similar to adult Anura. In the oral cavity of mature specimens gustatory organs only classified as TB-type were reported in axolotl Ambystoma mexican (Northcutt et al., 2000), Triturus pyrrhogaster (Toyoshima \& Shimamura, 1987) and Necturus maculosus (Cumnings et al., 1987; Delay \& Roper, 1988).

The purpose of this study was to investigate, with light and scanning electron microscopy, the dorsal epithelium of the gustatory organs type of the adult Chinese fire-bellied newt Cynops orientalis (David, 1873) and compare the results of the observations with those previous reported for those that of other Caudata. In order to clarify the relationship between the structure features of the gustatory organs and the lifestyles of newts that live in different environment.

\section{MATERIAL AND METHOD}

Twelve adult newt of both sexes, length approximately $40 \mathrm{~mm}$ and weighing 1.9-2.3 g, which were captured from countryside near Guangshui, Hubei province, China, were used in the present study. After anesthetization with a lethal dose of sodium pentobarbital, the animals were killed by decapitation. The livers were immediately taken for later analysis. For light microscopy, the samples were fixed in $10 \%$ neutral buffered formaldehyde and Bouin's solution without acetic acid (3:1 mixture of saturated solution of picric acid in water and formalin) for $48 \mathrm{~h}$. Samples were then dehydrated through a series of graded alcohols, cleared in xylene, infiltrated, and embedded into paraffin. Tongue 
paraffin wax blocks were cut into $7 \mu \mathrm{m}$ thick sections, stained with hematoxylin and eosin, and then they were examined under Nikon TE2000-U microscope.

For scanning electron microscopic (SEM) observation, tongue samples were fixed at $4{ }^{\circ} \mathrm{C}$ in $2.5 \%$ glutaraldehyde with phosphate buffer ( $\mathrm{pH}$ 7.2). After washing in fresh buffer, the tissues were additionally fixed for $1 \mathrm{~h} \mathrm{in} 1 \%$ buffered aqueous $\mathrm{O}_{\mathrm{S}} \mathrm{O}_{4}$ solution. They were dehydrated in a series of acetone concentration, starting with a 50\% solution, and then dried with critical-point-dryer, coated with gold and observed at various different angles under the scanning electron microscope (SEM) KYKYEM3200 at 5-15kV.

\section{RESULTS}

The tongue of Chinese fire-bellied presents around apex, measuring about $4.2 \mathrm{~mm}$ in length (except lingual root), $3.2 \mathrm{~mm}$ of width and $1.6 \mathrm{~mm}$ of thickness. Three parts are distinguished in the dorsal surface of the tongue: the apex, the body and the root. On the apex dorsal surface of the tongue, a large number of TDs are distributed by SEM observation. They are usually roundish or ellipsoidal in shape and are 20-35 $\mu \mathrm{m}$ in diameter (Fig. 1). The sensory epithelium of the TDs consist large mucous cells are relatively large irregular encircled by narrow apical sheet of 3-4 wing cells can be seen (Fig. 2). The strips of wing cells separate the mucous cells, where a tuft protruding apical microvillar processes are discernible. The surface of posterior part of tongue body distribute round knoblike structure about 5-10 $\mu \mathrm{m}$ in diameter can be seen (Fig.

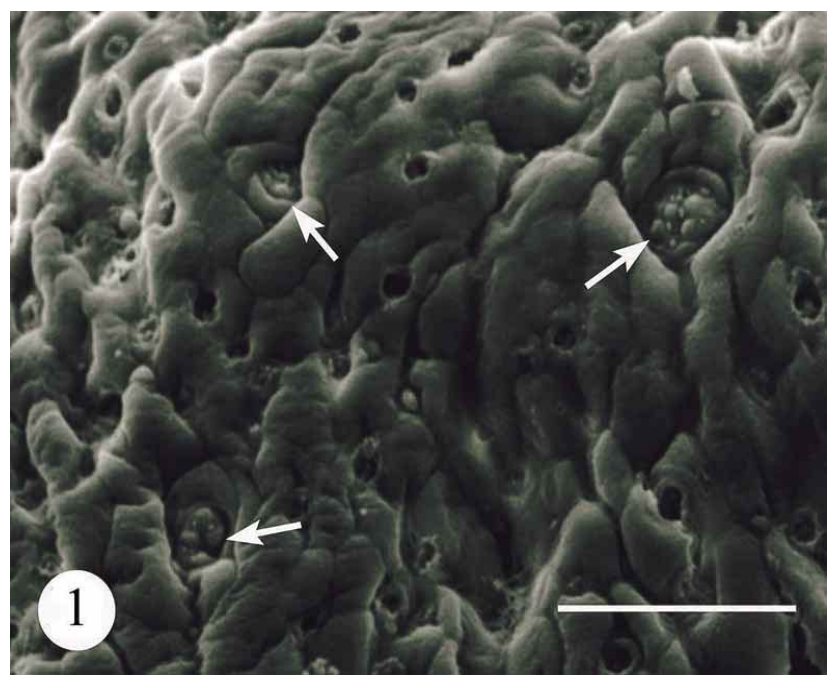

Fig. 1. Dorsal surface of the tongue of $C$. orientalis with developed taste discs (TDs, arrows). Scale bar $=50 \mu \mathrm{m}$.
3). Those processes presumed sensory cell. In some cases, a single opening is found at the lateral of the TD, outer

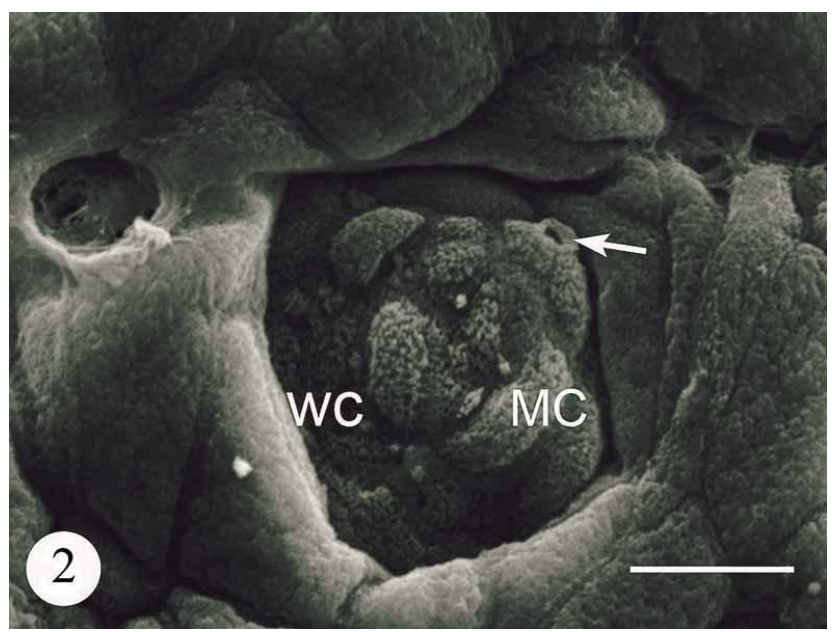

Fig. 2. Sensory area of lingual taste discs of $C$. orientalis, a single opening is found at the lateral of the TD (arrow). MC, mucous cell; WC, wing cell. Scale bar $=10 \mu \mathrm{m}$.

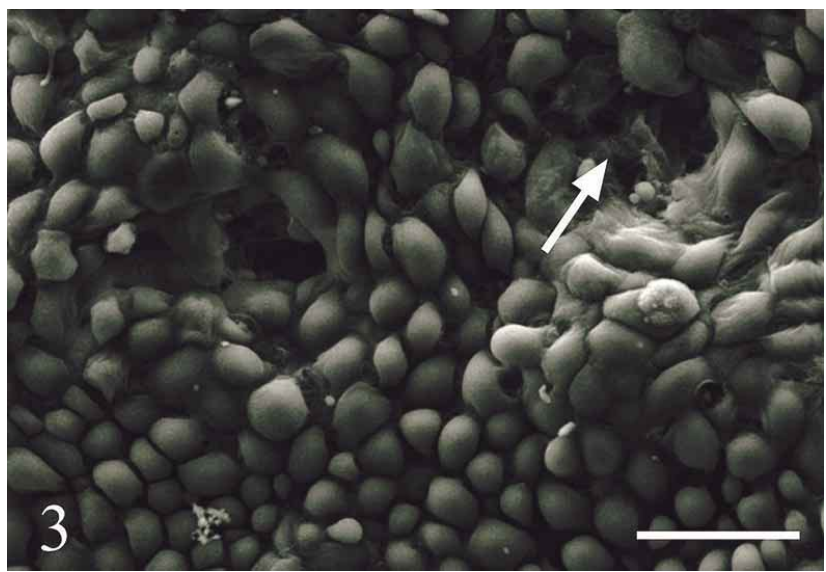

Fig. 3. The many openings of the lingual glands exist in the dorsolateral surface of lingual apex of $C$. orientalis. Scale bar $=10 \mu \mathrm{m}$.

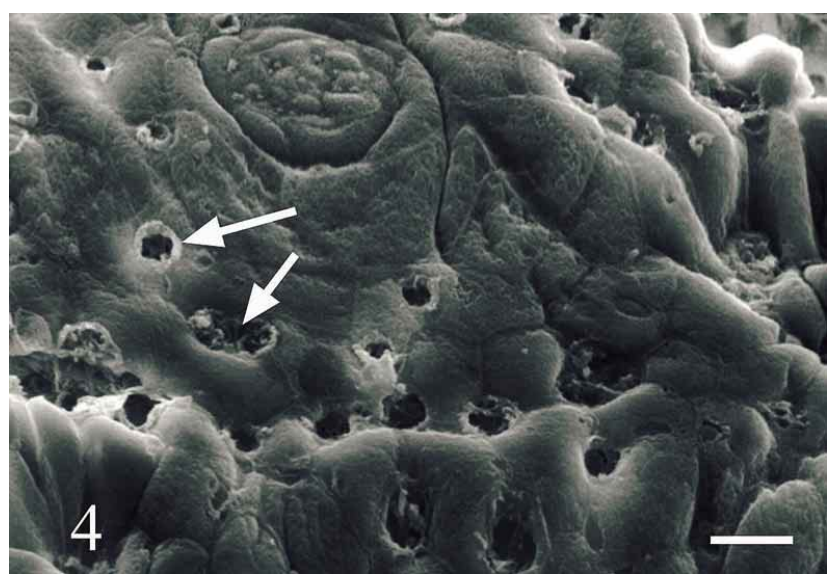

Fig. 4. The openings of the lingual glands in the lingual body of $C$. orientalis. Arrow, varying size pores integrated. Scale bar $=40 \mu \mathrm{m}$. 


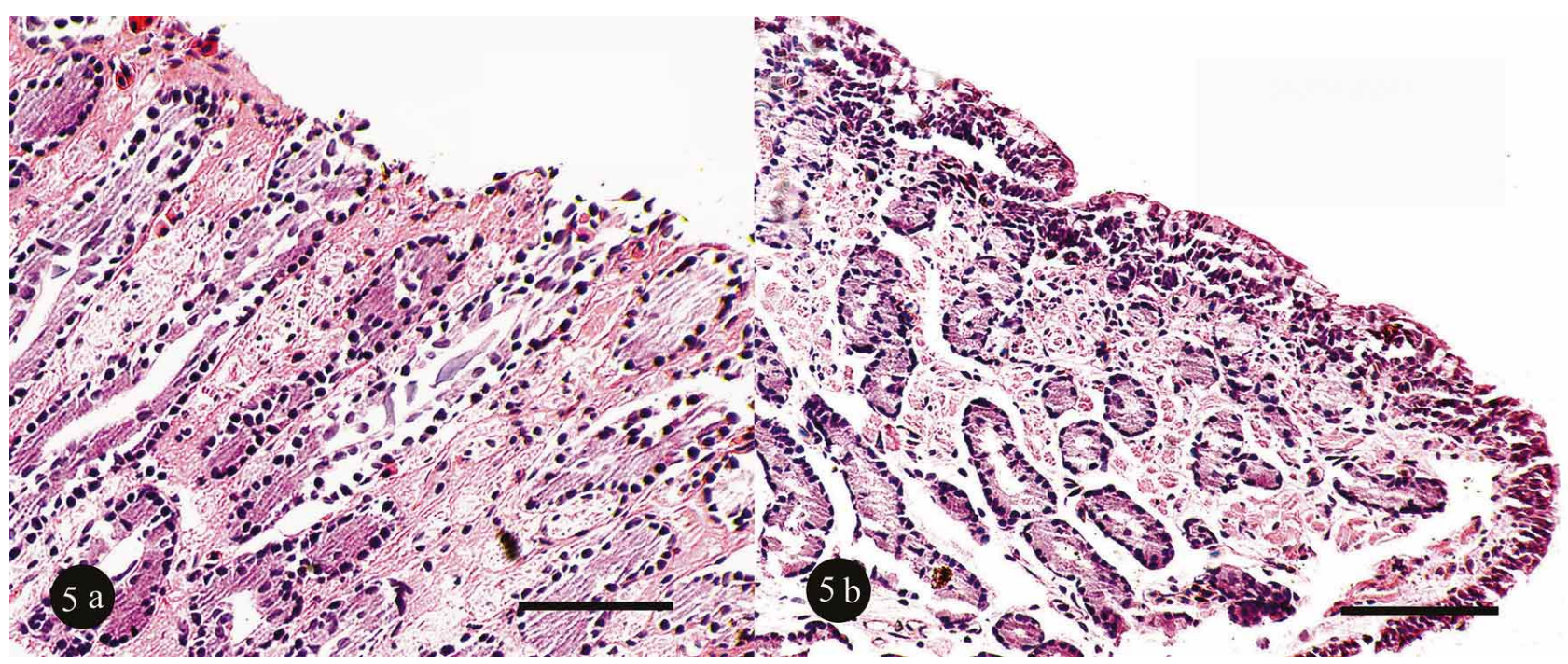

Fig. 5. The light microscopy examine the apex of the tongue of $C$. orientalis, the epithelial mucosal cells are arranged multi-layered. a. sagittal section; b, longitudinal section. Scale bar $=100 \mu \mathrm{m}$.

opening where semitransparent gelatinous substance attached to the orifice of the opening, a majority of TD have no opening. However, the many openings of the lingual glands, diameter in $4-8 \mu \mathrm{m}$, exist in the lateral border or median part of lingual body (Fig. 4).

By the light microscopy examinations of longitudinally sectioned show that on the apex of the tongue, the epithelial mucosal cells are arranged multi-layered, the cell number up to the highest at the bottom of the layers at the side. It consists of interlacing bundles of striated muscle that cross one another. The dense lamina propria is continuous with the interstitial connective tissue of the muscle. In vertical sections, the number of glandular ducts can be seen aligned in a rather amorphous substance (Fig. $5 \mathrm{a}$ and $5 \mathrm{~b})$. It is presumed to be glands of mucosa.

\section{DISCUSSION}

The present study demonstrated the characteristics of epithelial cell layers of Chinese fire-bellied tongue. Results indicated that the structure of the tongue in the Chinese fire-bellied does not differ from that present in other species in Caudates, such as Salamandra salamandra (Zuwala \& Jakubowski, 2001) and Hynobius dunni (Zuwala et al.), alpine newt Triturus alpestris (Zuwala \& Jakubowski, 2007) and a few Anuran families (Zuwala; Paulson et al., 1995).

Chinese fire-bellied belongs to the tailed amphibians in vertebrates, and amphibians usually live in and around freshwater, so the surface of the oral cavity around the tongue is wet, even on land, amphibians are not generally exposed to extremely dry conditions, and, consistently, no keratinization is found in the amphibian lingual epithelium (Iwasaki). In accord with our observation by SEM, that they were no keratinization of filiform papillae and circumvallate papillae.

The morphological and histological features of mammalian tongues reflect the differences among the lifestyles of mammals and relate to the animal habitat (Iwasaki). This animal's living habitat is widely distributed in the hilly plains of Central and Southeastern China from 30 to $1500 \mathrm{~m}$ above sea level (the provinces of Henan, Southern Anhui, Jiangsu, Zhejiang, Guangxi, Fujian, Southern Hubei, and Hunan). Their habitats are suitable water bodies at various altitudes, mountain ponds, small brooks and flooded fields in mountain valleys (Zhao \& $\mathrm{Hu}, 1988)$, as well as for many species of water-living animals, They use suction feeding for intraoral food transport, where water is drawn into the oral cavity by suddenly lowering the floor of the mouth, so that water movement is the main mechanism of intraoral food transport. Besides, the tongue occupies space within the oral cavity that could otherwise be utilized for volumetric expansion and suction (Beisser et al., 1998).

There are taste disks distributed on the dorsal surface of the tongue both the apex and body, at the same time, a large number of tongue gland openings distributed around the TDs nearly, and the secretions can continuously flushing the ring groove of gustatory cells, the clearance of bacteria impurities and food residue, it is good for the 
TDs to feel the different flavors of food stimulation, which reveals that the living environment of Chinese fire-bellied is more stringent. Chinese fire-bellied mainly prey on aquatic insects, insect eggs and other small aquatic animals, the living environment of the waters clear, with the aquatic plant growing, so the high requirements of food fresh and living environment leads to the development of sensitive taste receptor. As for the distribution of a large number of TDs and taste glands in the tongue body, probably for its smooth swallowing and plays an important role in the completion on eating food, and is also helpful for the Chinese fire-bellied to swallow food associated with fixed food by mucus. Nomura et al. (1979), studied the structure of the oral cavity lining in tadpoles of Rana japonica, and described a group of innervated cells in the apex of each premetamorphic, suggesting that they may have a chemoreceptive function.

\section{ACKNOWLEDGEMENTS}

This work was supported by a grant from the Foundational and Advanced Techniques Foundation of Henan, China (122300410356). We would like to thank, and are grateful to Prof. Yujie HOU for her great help in the specimen collection and senior experimentalist Xinai ZHU in microscopy from College of Life Sciences and Key Laboratory for Cell Differentiation Regulation, Henan Normal University for visualizing the samples.

XIE, Z.; LI, J. \& CHENG, P. Características de los órganos gustativos en la lengua del tritón vientre de fuego Chino (Cynops orientalis): estudio por microscopía de luz y electrónica de barrido. Int. J. Morphol., 32(3):930-934, 2014.

RESUMEN: La superficie dorsal de la lengua de los órganos gustativos del tritón de vientre de fuego chino (Cynops orientalis) se observó mediante microscopía de luz y electrónica de barrido (SEM). Los resultados revelaron que la parte rostral y mediana de la lengua presenta un ápice redondo y cubierto por discos sensoriales. Estos por lo general tienen una forma redondeada o elipsoidal con un diámetro de 20-35 mm. Las numerosas aperturas de las glándulas linguales tienen un diámetro de 4-8 mm en el margen lateral o en la parte mediana de cuerpo lingual. No se observaron diferencias en los órganos gustativos linguales al comparar estos con otras especies de caudados. Estos pueden indicar funciones de los órganos gustativos de la lengua relacionadas con su hábito de vida.

PALABRAS CLAVE: Lengua; Epitelio lingual; Histología; Discos sensoriales; Caudados.

\section{REFERENCES}

Abbate, F.; Guerrera, M. C.; Montalbano, G.; Zichichi, R.; Germanà, A. \& Ciriaco, E. Morphology of the lingual dorsal surface and oral taste buds in Italian lizard (Podarcis sicula). Anat. Histol. Embryol., 39(2):167-71, 2010.

Beisser, C. J.; Weisgram, J.; Hilgers, H. \& Splechtna, H. Fine structure of the dorsal lingual epithelium of Trachemys scripta elegans (Chelonia: Emydidae). Anat. Rec., 250(2):127-35, 1998.

Cummings, T. A.; Delay, R. J. \& Roper, S. D. Ultrastructure of apical specializations of taste cells in the mudpuppy, Necturus maculosus. J. Comp. Neurol., 261(4):604-15, 1987.

Delay, R. J. \& Roper, S. D. Ultrastructure of taste cells and synapses in the mudpuppy Necturus maculosus. J. Comp. Neurol., 277(2):268-80, 1988.

Graziadei, P. P. C. \& DeHan, R. S. The ultrastructure of frogs' taste organs. Acta Anat. (Basel), 80(4):563-603, 1971.

Iwasaki, S. Evolution of the structure and function of the vertebrate tongue. J. Anat., 201(1):1-13, 2002.
Iwasaki, S.; Miyata, K. \& Kobayashi, K. Fine structures of the filiform papillar epithelium in the tongue of the frog, Rana nigromaculata. Zool. Sci., 5:61-8, 1989a.

Iwasaki, S.; Miyata, K. \& Kobayashi, K. Fine structures of the lingual dorsal epithelium of the Japanese toad, Bufo japonicus (Anura, Bufonidae). Zool. Sci., 6:681-9, 1989b.

Iwasaki, S. \& Wanichanon, C. An ultrastructural study of the dorsal lingual epithelium of the crab-eating frog, Rana cancrivora. J. Morphol., 215(1):89-100, 2005.

Mistretta, C. M. \& Liu, H. X. Development of fungiform papillae: patterned lingual gustatory organs. Arch. Histol. Cytol., 69(4):199-208, 2006.

Nomura, S.; Shiba, Y.; Muneoka, Y. \& Kanno, Y. A scanning and transmission electron microscope study of the premetamorphic papillae: possible chemoreceptive organs in the oral cavity of an anuran tadpole (Rana japonica). Arch. Histol. Jpn., 42(5):507-16, 1979

Northcutt, R. G.; Barlow, L. A.; Braun, C. B. \& Catania, K. C. 
XIE, Z.; LI, J. \& CHENG, P. Characteristic of the gustatory organs on the tongue of the chinese fire-bellied newt (Cynops orientalis): light and scanning electron microscopy study. Int. J. Morphol., 32(3):930-934, 2014

Distribution and innervation of taste buds in the axolotl. Brain Behav. Evol., 56(3):123-45, 2000.

Osculati, F. \& Sbarbati, A. The frog taste disc: a prototype of the vertebrate gustatory organ. Prog. Neurobiol., 46(4):351-99, 1995.

Paulson, R. B.; Alley, K. E.; Salata, L. J. \& Whitemyer, C. C. A scanning electron-microscopic study of tongue development in the frog Rana pipiens. Arch. Oral Biol., 40(4):311-9, 1995.

Toyoshima, K. \& Shimamura, A. Monoamine-containing basal cells in the taste buds of the newt Triturus pyrrhogaster. Arch. Oral Biol., 32(9):619-21, 1987.

Witt, M. Ultrastructure of the taste disc in the red-bellied toad Bombina orientalis (Discoglossidae, Salientia). Cell Tissue Res., 272(1):59-70, 1993.

Zhao, E. M. \& Hu, Q. X. Studies on Chinese salamanders. In: Zhao, E. M.; Hu, Q. X.; Jiang, Y. M. \& Yang, Y. H. (Eds.). Studies on Chinese tailed amphibians. Oxford $(\mathrm{OH})$, Society for the study of amphibians and reptiles, 1988. pp.1-48.

Zuwala, K. Development of the tongue and taste disks in Pelobates fuscus. Folia Biol. (Krakow), 50(3-4):165-72, 2002.

Zuwala, K. \& Jakubowski, M. Two types of taste organs (SEM, TEM) in the development of the spotted salamander Salamandra salamandra (L). Anat. Embryol., 204:413-20, 2001.

Zuwala, K. \& Jakubowski, M. Structural diversification of the gustatory organs during metamorphosis in the alpine newt Triturus alpestris. J. Anat., 211(3):371-5, 2007.

Zuwala, K.; Kato, S. \& Jakubowski, M. Two generations of the tongue and gustatory organs in the development of Hynobius dunni Tago. J. Anat., 201(1):91-7, 2002.

Zylberberg, L. Histochemistry and ultrastructure of amphibian lingual glands and phylogenetic relations. Histochem. J., 9(4):505-20, 1977.

\section{Correspondence to: Dr. Zhaohui Xie School of Life Science and Engineering Henan University of Urban Construction Pingdingshan 467000, Henan, CHINA}

Email: xiezhaohui@hncj.edu.cn

Received: 05-11-2013

Accepted: 26-05-2014 